\title{
Effect of Biochar and Inorganic Fertilizer in Yam (Dioscorea rotundata Poir) Production in a Forest Agroecological Zone
}

\author{
Mavis Akom ${ }^{1}$, Charles Oti-Boateng ${ }^{2}$, Emmanuel Otoo $^{1} \&$ Evans Dawoe $^{2}$ \\ ${ }^{1}$ CSIR - Crops Research Institute, Kumasi, Ghana \\ ${ }^{2}$ Kwame Nkrumah University of Science and Technology (KNUST), Kumasi, Ghana \\ Correspondence: Mavis Akom, CSIR - Crops Research Institute, Kumasi, Ghana. Tel: 233-516-0389. E-mail: \\ numafo11@yahoo.com
}

$\begin{aligned} & \text { Received: November 26, } 2014 \quad \text { Accepted: January 4, } 2015 \quad \text { Online Published: February 15, } 2015 \\ & \text { doi:10.5539/jas.v7n3p211 }\end{aligned}$ URL: http://dx.doi.org/10.5539/jas.v7n3p211

\begin{abstract}
Yam production is characterized by low fertilizer input and annual shifting in search for fertile lands. This practice usually leads to reduction in the yield potential of the crop and destruction of the environment. Biochar additions through its ability to improve soil fertility and increase crop yields could be used to solve these problems. This study therefore investigated the effect of biochar and inorganic fertilizer application on yam production in a forest agro ecological zone in Ghana. A $4 \times 3$ factorial experiment in a randomised complete block design with three replications was used. The treatments consisted of four application rates of wood shaving biochar $\left(0 \mathrm{tha}^{-1}, 5 \mathrm{tha}^{-1}, 10 \mathrm{tha}^{-1}\right.$ and $\left.15 \mathrm{tha}^{-1}\right)$ and three inorganic fertilizer rates $\left(0-0-0 \mathrm{~N}-\mathrm{P}_{2} \mathrm{O}_{5}-\mathrm{K}_{2} \mathrm{O} \mathrm{kg} \mathrm{ha}{ }^{-1}\right.$, 30-30-30 N-P $\mathrm{P}_{2} \mathrm{O}_{5}-\mathrm{K}_{2} \mathrm{O}$ kg ha ${ }^{-1}$ and 60-60-60 N-P $\left.\mathrm{P}_{2} \mathrm{O}_{5}-\mathrm{K}_{2} \mathrm{O} \mathrm{kg} \mathrm{ha}{ }^{-1}\right)$. No significant differences in soil parameters in response to the treatment were observed, with the exception of total $\mathrm{N}$, where a decline was observed for all the treatments compared to the controls after harvest. Vegetative growth parameters of yam were not significantly influenced by biochar and inorganic fertilizer application. The number of seed yams per hectare was the only yield parameter that was significantly $(\mathrm{p}=0.05)$ decreased by biochar application. Dry matter, production was also significantly $(\mathrm{p}=0.05)$ increased by fertilizer application at 24 weeks after planting and at harvest. It is suggested that aged and higher rates of biochar would efficiently support yam production.
\end{abstract}

Keywords: biochar, inorganic fertilizer, vegetative growth, yam, yield

\section{Introduction}

Yam (Dioscorea spp.) constitutes an important starchy staple in sub-Saharan Africa (SSA) where food security for the growing population is a critical issue (O'Sullivan, 2010). The yam zone in West Africa produces about 95 $\%$ of the world yam production of about 59 million tons in 2012 (FAO, 2012). The crop contributes more than 200 dietary calories per capita daily for more than 150 million people in West Africa and serves as an important source of income to the people (Babaleye, 2003).

Yams require soils of high fertility and are traditionally grown as the first crop after clearing the land. Its production is therefore characterized by shifting cultivation on yearly basis as farmers move in search of more fertile soils to sustain yields. Increases in yam production in Africa are mostly as a result of expansion in cultivated area. For example the increase in yam production from 41 million tons to 57 million tons during the 2002-2012 periods was as a result of a $17.1 \%$ increase in cultivated area (FAO, 2012). Production of yam therefore has the potential of degrading the environment in the long-term (Otoo, Anchirinah, Ennin, \& Asiedu, 2008) as a result of the rapid depletion of soil nutrients and in some cases the deterioration of soil physical conditions.

Pressure on land for other purposes as a result of population increase with its changing socio-economic habitat, has led to shorter fallow periods. In addition the environmental effect of annual shifting cultivation has made yam production on previously used land necessary. This practice however usually leads to a reduction in the yield potential of the crop as a result of intensive cropping often without nutrient supplement.

The use of fertilizers, improved fallow systems, herbaceous legume rotation systems and agroforestry systems have been promoted and used to improve soil fertility and increase yield of yam (Akanbi, Olaniran, \& Olaniyan, 2007; Adeleye, Ayeni, \& Ojeniyi, 2010; Ernest \& O’Sullivan, 2004). However the high price and low 
accessibility of inorganic fertilizers by resource-poor farmers, the rapid mineralization of organic fertilizers under tropical conditions after a few growing seasons and its bulkiness as well as the labour intensiveness of agroforestry systems has resulted in limited use by farmers. In addition, the benefits of organic matter from organic amendments are usually mineralized to $\mathrm{CO}_{2}$ within a few cropping seasons (Bol, Amelung, Friedrich, \& Ostle, 2000) and have to be applied with each growing season to sustain soil productivity.

Recent studies have shown the ability of charred biomass or biochar to improve soil quality, increase crop production and also have a long turnover time in the soil (Lehmann et al., 2003 ; Chan, Van Zwieten, Meszaros, Downie, \& Joseph, 2008; Chintala et al., 2014a). The high surface area and porosity of biochar enable it to adsorb or retain nutrients and water (Chintala et al., 2013a; Chintala et al., 2013b), provide habitat for beneficial microorganisms to flourish and reduce the soil's nutrient depletion rate. Biochar also maintains a maximum amount of $\mathrm{C}$ in the soil as a result of its stability against microbial decay (Baldock \& Smernik, 2002; Chintala et al., 2013a; Chintala, 2014b).

While the use of biochar with and without fertilizer has been reported for cereals, vegetables and legumes production (Karve et al., 2009; Solaiman, Blackwell, Abbott, \& Storer, 2010), there is no reported work on its effects on yam, which is an important staple crop in West Africa. This study was therefore undertaken to investigate the agronomic effect of biochar and inorganic fertilizer application on yam production in a forest agroecological zone of Ghana.

\section{Methods and Materials}

\subsection{Study Area}

The study was conducted on the research field of Crops Research Institute (CRI) at Fumesua, Kumasi-Ghana from March to December 2012. Fumesua is located on latitude $06^{\circ} 41^{\prime} \mathrm{N}$ and longitude $01^{\circ} 28^{\prime} \mathrm{W}$ in the humid forest agro-ecological zone of Ghana. The area is characterized by a bimodal rainfall pattern with the major season spanning March to mid-August with a peak in June and a minor season from September to November which peaks in October. The annual rainfall of the area ranges between $1190-1650 \mathrm{~mm}$ with an average of 1345 $\mathrm{mm} /$ year, while the mean annual temperature is between $22-31{ }^{\circ} \mathrm{C}$. The soil type at the study site is a Ferric Acrisol, Asuansi series with a slope of 2-6\% (Adu \& Asiamah, 1992). Weather data during the trial study period was obtained from the CRI weather station and presented in Table 1.

Table 1. Monthly rainfall $(\mathrm{mm})$, Temperature $\left({ }^{\circ} \mathrm{C}\right)$, Relative humidity $(\%)$ and Solar radiation recorded at the study area for 2012

\begin{tabular}{|c|c|c|c|c|c|}
\hline \multirow{2}{*}{ Month } & \multirow{2}{*}{ Rainfall (mm) } & \multicolumn{2}{|c|}{ Temp $\left({ }^{0} \mathrm{C}\right)$} & \multirow{2}{*}{ RH (\%) } & \multirow{2}{*}{ Solar radiation $\left(W / \mathbf{m}^{2}\right)$} \\
\hline & & Min & Max & & \\
\hline Jan & 9.00 & 25.86 & 28.52 & 61.02 & 156.59 \\
\hline Feb & 17.80 & 26.71 & 30.15 & 70.01 & 164.68 \\
\hline Mar & 82.40 & 27.22 & 30.17 & 76.76 & 184.90 \\
\hline Apr & 152.61 & 26.68 & 29.82 & 83.46 & 181.36 \\
\hline May & 170.43 & 26.15 & 29.42 & 85.28 & 167.07 \\
\hline Jun & 202.83 & 24.92 & 28.09 & 89.46 & 138.28 \\
\hline Jul & 43.60 & 24.09 & 27.15 & 89.12 & 118.22 \\
\hline Aug & 4.60 & 23.99 & 26.73 & 86.73 & 102.15 \\
\hline Sep & 46.60 & 25.02 & 28.13 & 86.69 & 121.41 \\
\hline Oct & 215.22 & 25.34 & 28.69 & 88.42 & 154.94 \\
\hline Nov & 41.40 & 26.17 & 29.27 & 85.16 & 156.04 \\
\hline Dec & 40.80 & 25.89 & 28.75 & 80.09 & 149.13 \\
\hline
\end{tabular}

Source: CSIR-Crops Research Institute weather station.

\subsection{Experimental Design, Biochar Production and Land Preparation}

The experimental design was a randomised complete block design with three replicates of $5 \mathrm{~m} \mathrm{x} 4 \mathrm{~m}$ plots. The treatments consisted of two factors, wood shavings biochar with four levels of $\left(\mathrm{B} 1=0 \mathrm{tha}^{-1}, \mathrm{~B} 2=5 \mathrm{tha} \mathrm{h}^{-1}, \mathrm{~B} 3=\right.$ 
$10 \mathrm{tha}^{-1}$ and B4 $\left.=15 \mathrm{tha}^{-1}\right)$ and fertilizer application with three levels $\left(\mathrm{F} 1=0-0-0 \mathrm{~N}-\mathrm{P}_{2} \mathrm{O}_{5}-\mathrm{K}_{2} \mathrm{O} \mathrm{kg} \mathrm{ha}{ }^{-1}, \mathrm{~F} 2=\right.$ $30-30-30 \mathrm{~N}-\mathrm{P}_{2} \mathrm{O}_{5}-\mathrm{K}_{2} \mathrm{O}$ kg ha ${ }^{-1}$ and $\mathrm{F} 3=60-60-60 \mathrm{~N}-\mathrm{P}_{2} \mathrm{O}_{5}-\mathrm{K}_{2} \mathrm{O}$ kg ha ${ }^{-1}$ ).

The wood shaving feedstock used for the study was collected as waste from a local wood mill. The pyrolysis process was carried out in a locally designed reactor and heated with fuel wood also collected as waste from the local wood mill. The temperature inside the rector was monitored with a thermocouple and had an average temperature of $400^{\circ} \mathrm{C}$ with an average of three days to carbonising.

The site was slashed, ploughed, harrowed and the residues removed without burning. Soil samples were randomly taken from the field after which the different levels of biochar were spread and incorporated into appropriate plots before constructing the mounds. The mounds were constructed in rows and were about $30 \mathrm{~cm}$ high. There were 20 mounds per plot at a spacing of $1 \mathrm{~m} \times 1 \mathrm{~m}$.

\subsection{Soil Sampling and Biochar Analysis}

Soil samples were randomly taken before planting from four different spots across each replicate at a depth of 0-20 cm using soil auger. Samples were bulked and sub-samples taken, air-dried and crushed in a mortar with a pestle to pass through a $2 \mathrm{~mm}$ sieve before being analysed using routine analysis methods. Samples of the biochar were also taken from the prepared biochar bulked and ground into powder before being analysed. The physical and chemical properties of both the soil and biochar were assessed. Soil samples were again taken at the same depth at harvest and analysed for the same parameters. The analysis of soil sample before planting and biochar samples are presented in Tables 2 and 3.

Soil $\mathrm{pH}$ was determined with WTW $\mathrm{pH}$ - electrode Sen Tix 41 meter calibrated with buffer solutions at $\mathrm{pH} 4$ and 7. Organic matter (OM) and Carbon were measured by the dry combustion method (Chintala et al., 2013c). Total $\mathrm{N}$ was determined by the Kjeldahl distillation method, available $\mathrm{P}$ was by the Bray-1 method. Exchangeable cations ( $\mathrm{Ca}, \mathrm{Mg}, \mathrm{K}$ and $\mathrm{Na}$ ) were extracted with $1.0 \mathrm{~N} \mathrm{NH}_{4} \mathrm{OAc}$ using a soil solution volume ratio of 1:10. The $\mathrm{K}$ and $\mathrm{Na}$ in the extract were read using a flame photometer, while $\mathrm{Ca}$ and $\mathrm{Mg}$ content in the extract was read on the atomic absorption spectrophotometer (Chintala et al., 2014a). Exchangeable acidity $\left(\mathrm{H}^{+}\right.$and $\left.\mathrm{Al}^{3+}\right)$ was measured from $1 \mathrm{~N} \mathrm{KCl}$ extracts by titrating with $0.05 \mathrm{~N} \mathrm{HC1}$ (Chintala et al., 2014a) while particle size distribution was determined using hydrometer method.

Table 2. Physicochemical properties $(0-20 \mathrm{~cm})$ of the experimental site

\begin{tabular}{ll}
\hline Soil parameters & Value \\
\hline $\mathrm{pH}(\mathrm{H} 2 \mathrm{O})$ & 5.18 \\
Organic C $(\%)$ & 2.99 \\
Organic matter $(\%)$ & 5.15 \\
Total N (\%) & 0.13 \\
Available P ppm & 10.74 \\
Exchangeable cations $\left(\mathrm{cmol}_{\mathrm{c}} / \mathrm{kg}\right)$ & \\
$\mathrm{Ca}$ & 6.60 \\
$\mathrm{Mg}$ & 1.00 \\
$\mathrm{~K}$ & 0.12 \\
$\mathrm{Na}$ & 0.19 \\
$\mathrm{Al}$ & 0.40 \\
$\mathrm{H}$ & 4.00 \\
Exchangeable acidity $(\mathrm{Al}+\mathrm{H}) \quad\left(\mathrm{cmol}_{\mathrm{c}} / \mathrm{kg}\right)$ & 4.40 \\
Effective cation exchange capacity $\left(\mathrm{cmol}_{\mathrm{c}} / \mathrm{kg}\right)$ & 11.71 \\
Base saturation $(\%)$ & 23.00 \\
Bulk density $\left(\mathrm{g} / \mathrm{cm}^{3}\right)$ & 1.43 \\
Texture $(\%)$ & \\
Sand & 71.60 \\
Silt & 10.00 \\
Clay & 18.40 \\
Textural Class & sandy loam \\
\hline
\end{tabular}


Table 3. Physicochemical properties of the biochar used for the experiment

\begin{tabular}{lllllllllllll}
\hline Biochar & $\mathbf{p H}\left(\mathbf{H}_{\mathbf{2}} \mathbf{O}\right)$ & $\mathbf{P}_{\mathbf{a}}$ & $\mathbf{K}$ & $\mathbf{C a}\left(\mathbf{c m o l k g}^{-1}\right)$ & $\mathbf{M g}$ & $\mathbf{N a}$ & Org. $\mathbf{M}$ & Org. C & Total N (\%) & Ash & C:N & Bulk density \\
\hline & 7.27 & 3.87 & 2.56 & 30.95 & 7.82 & 8.7 & 95.22 & 55.24 & 0.21 & 3.6 & 263.1 & 0.18 \\
\hline
\end{tabular}

Note. ${ }^{a}$ available nutrients.

\subsection{Planting Materials and Cultural Practices}

Yam setts with average weight of $300 \mathrm{~g}$ were treated with liquid mixture of Conti-Zeb ' 5 ' (mancozeb 80\%) and Dursban (480 g/l chlorpyrifos) and planted one per plot at the beginning of the rainy season. Each mound was mulched with a tuft of dried grasses and the yam staked. Fertilizer was split-applied at 8 and 16 weeks after planting (WAP). The field was sprayed with Roundup (360 g/l Glyphosate) before sprouting of the setts to control weeds. Hand-weeding was subsequently carried out using a hoe as and when necessary.

\subsection{Crop Growth and Measurement}

The vine length, vine girth and number of leaves were measured from five plants randomly selected from the middle row of each plot at monthly intervals. Vine girth was measured using a calliper at $10 \mathrm{~cm}$ above the mound, vine length with a tape measure and line whiles the number of leaves and sprouts were determined by count.

Two plants per plot were selected from the border rows and destructively sampled at 8 and 24 weeks after planting (WAP) and at harvest (37 WAP) for dry matter assessment. Yield and its parameters were assessed on yam tubers harvested from the two middle rows at 32 WAP when the plant had senesced.

\subsection{Statistical Analysis}

Statistical Analysis Systems (SAS) package version 9.2 was used for statistical analysis of all the soil, growth and yield parameters. Analysis of variance and means separations were done by the general linear model procedure. The least significant difference (LSD) test was used to determine significant differences $(p<0.05)$ between means.

\section{Results}

\subsection{Soil Chemical Properties after Harvest}

Addition of biochar and fertilizer resulted in a general increase in most of the soil parameters studied (Tables 2 and 4). The magnitude of increase was however marginal and not significant. Similarly, among the treatments, soil chemical properties after harvest were not significant with the exception of total $\mathrm{N}$ which was found to have declined significantly $(\mathrm{p}=0.02)$ (Table 4$)$. A decline in total $\mathrm{N}$ was observed for all the treatments compared to the control. Fertilization was found to have significantly $(\mathrm{p}=0.01)$ decreased soil $\mathrm{pH}$ by $6.4 \%$ and $7.2 \%$ and increased soil $\mathrm{K}(\mathrm{p}=0.003)$ by $51.9 \%$ at $30-30-30 \mathrm{~N}-\mathrm{P}_{2} \mathrm{O}_{5}-\mathrm{K}_{2} \mathrm{O} \mathrm{kg}^{-1}$ and $60-60-60 \mathrm{~N}-\mathrm{P}_{2} \mathrm{O}_{5}-\mathrm{K}_{2} \mathrm{O}$ kg ha ${ }^{-1}$ fertilizer rate respectively compared to the control (Figure 1 and Figure 2).

Table 4. Chemical properties of the soil used for the experiment after harvest

\begin{tabular}{|c|c|c|c|c|c|c|c|c|c|c|c|}
\hline & $\mathrm{pH}\left(\mathrm{H}_{2} \mathrm{O}\right)$ & $\mathbf{P a}$ & $\mathbf{K}$ & Ca (cmolkg-1) & Mg & $\mathbf{N a}$ & Org. M & Org. C (\%) & Total N & $\mathrm{C}: \mathrm{N}$ & CEC \\
\hline B1F1 & 5.81 & 24.61 & 0.39 & 11.80 & 2.00 & 0.46 & 7.28 & 4.22 & 0.21 & 20.59 & 19.75 \\
\hline $\mathrm{B} 1 \mathrm{~F} 2$ & 5.16 & 5.63 & 0.39 & 6.30 & 1.30 & 0.36 & 5.30 & 3.08 & 0.14 & 21.96 & 15.34 \\
\hline B1F3 & 5.31 & 13.31 & 0.49 & 8.06 & 2.00 & 0.55 & 6.92 & 4.01 & 0.17 & 24.52 & 18.49 \\
\hline $\mathrm{B} 2 \mathrm{~F} 1$ & 5.41 & 6.16 & 0.19 & 6.50 & 1.30 & 0.35 & 3.08 & 1.79 & 0.14 & 13.54 & 15.53 \\
\hline $\mathrm{B} 2 \mathrm{~F} 2$ & 5.19 & 6.28 & 0.50 & 9.00 & 3.30 & 0.53 & 5.84 & 3.38 & 0.14 & 25.21 & 20.42 \\
\hline $\mathrm{B} 2 \mathrm{~F} 3$ & 5.28 & 5.16 & 0.38 & 10.50 & 3.30 & 0.40 & 6.01 & 3.49 & 0.17 & 20.50 & 21.37 \\
\hline B3F1 & 5.29 & 6.05 & 0.21 & 8.90 & 2.10 & 0.37 & 4.94 & 2.87 & 0.15 & 19.66 & 18.78 \\
\hline $\mathrm{B} 3 \mathrm{~F} 2$ & 5.27 & 7.98 & 0.35 & 8.50 & 2.40 & 0.37 & 4.95 & 2.87 & 0.18 & 15.94 & 19.12 \\
\hline $\mathrm{B} 3 \mathrm{~F} 3$ & 5.07 & 8.74 & 0.39 & 9.20 & 2.40 & 0.40 & 6.32 & 3.67 & 0.16 & 23.71 & 19.98 \\
\hline B4F1 & 5.87 & 11.14 & 0.30 & 7.60 & 0.40 & 0.35 & 6.77 & 3.93 & 0.15 & 27.17 & 13.99 \\
\hline B4F2 & 5.33 & 6.52 & 0.41 & 9.30 & 3.40 & 0.31 & 5.51 & 3.19 & 0.19 & 16.96 & 20.51 \\
\hline B4F3 & 5.14 & 9.96 & 0.40 & 7.80 & 1.70 & 0.38 & 6.21 & 3.61 & 0.16 & 23.31 & 17.67 \\
\hline LSD & ns & ns & ns & ns & ns & ns & ns & ns & $0.0^{* *}$ & ns & ns \\
\hline
\end{tabular}




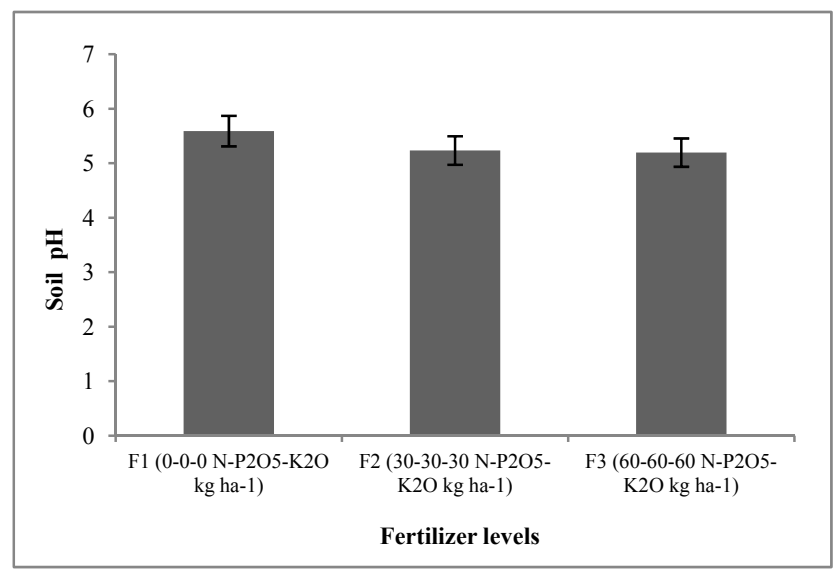

Figure 1. Effect of fertilizer application on soil $\mathrm{pH}$ after harvest

Note. Error bars represent standard error of means.

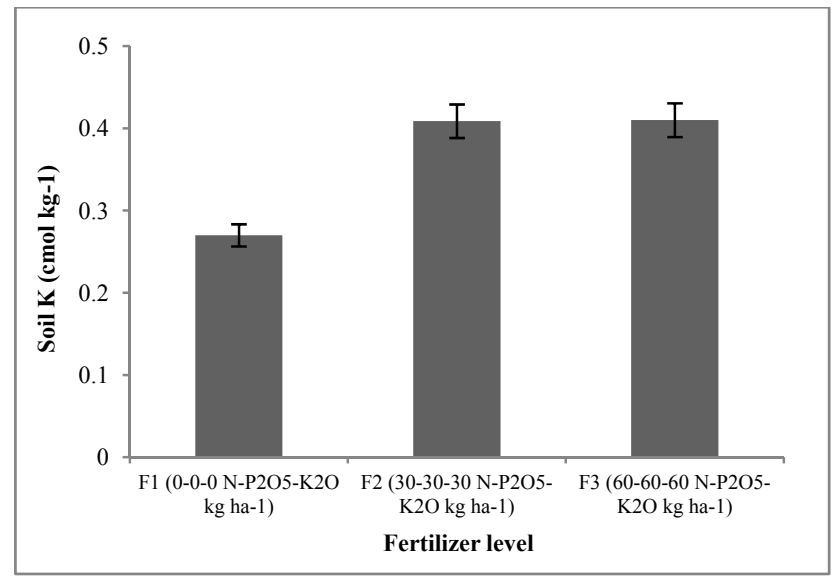

Figure 2. Fertilizer effect on soil $\mathrm{K}$ after harvest

Note. Error bars represent standard error of mean.

\subsection{Vegetative Growth Parameters}

Vegetative growth parameters of yam were not significantly influenced by biochar and inorganic fertilizer application (Table 5). There was no definite trend in the sprouting rate. Sprouting started in all treatments at approximately the $2^{\text {nd }}$ month after planting. Vine girth per plant also did not follow any definite trend although there was an increase in all the treatments compared to the control. The treatment effects on vine length per plant and number of leaves per plant followed a similar trend to vine girth per plant. 
Table 5. Effect of biochar and inorganic fertiliser application on the vegetative growth of yam

\begin{tabular}{|c|c|c|c|c|c|c|c|c|c|c|}
\hline & \multicolumn{4}{|c|}{ Growth at 2 MAP } & \multicolumn{4}{|c|}{ Growth at 3 MAP } & \multicolumn{2}{|c|}{ Growth at 4 MAP } \\
\hline & $\begin{array}{l}\text { Stand } \\
\text { count } \\
\left(\mathrm{ha}^{-1}\right)\end{array}$ & $\begin{array}{l}\text { Vine } \\
\text { girth } \\
\text { plant }^{-1} \\
(\mathrm{~cm})\end{array}$ & $\begin{array}{l}\text { Vine } \\
\text { length } \\
\text { plant }^{-1} \\
(\mathrm{~m})\end{array}$ & $\begin{array}{l}\text { Number } \\
\text { of leaves } \\
\text { plant }^{-1}\end{array}$ & $\begin{array}{l}\text { Stand } \\
\text { count } \\
\left(\mathrm{ha}^{-1}\right)\end{array}$ & $\begin{array}{l}\text { Vine } \\
\text { girth } \\
\text { plant }^{-1} \\
(\mathrm{~cm})\end{array}$ & $\begin{array}{l}\text { Vine } \\
\text { length } \\
\text { plant }^{-1} \\
(\mathrm{~m})\end{array}$ & $\begin{array}{l}\text { Number } \\
\text { of leaves } \\
\text { plant }^{-1}\end{array}$ & $\begin{array}{l}\text { Stand } \\
\text { count } \\
\left(\mathrm{ha}^{-1}\right)\end{array}$ & $\begin{array}{l}\text { Vine girth } \\
\text { plant }^{-1} \\
(\mathrm{~cm})\end{array}$ \\
\hline B1F1 & 5666.67 & 0.12 & 0.21 & 3.18 & 7000.00 & 0.12 & 0.29 & 13.51 & 9666.67 & 0.13 \\
\hline $\mathrm{B} 1 \mathrm{~F} 2$ & 5333.33 & 0.13 & 0.21 & 3.53 & 7500.00 & 0.13 & 0.33 & 15.03 & 9666.67 & 0.14 \\
\hline B1F3 & 4666.67 & 0.14 & 0.22 & 3.73 & 7166.67 & 0.13 & 0.33 & 15.70 & 9583.33 & 0.14 \\
\hline $\mathrm{B} 2 \mathrm{~F} 1$ & 3000.00 & 0.14 & 0.22 & 4.42 & 5583.33 & 0.13 & 0.34 & 16.55 & 8416.67 & 0.14 \\
\hline $\mathrm{B} 2 \mathrm{~F} 2$ & 7000.00 & 0.14 & 0.22 & 8.34 & 7750.00 & 0.14 & 0.35 & 18.33 & 9666.67 & 0.14 \\
\hline $\mathrm{B} 2 \mathrm{~F} 3$ & 3666.67 & 0.14 & 0.25 & 8.42 & 6416.67 & 0.14 & 0.36 & 19.19 & 9500.00 & 0.14 \\
\hline B3F1 & 4666.67 & 0.14 & 0.29 & 14.22 & 7250.00 & 0.15 & 0.42 & 23.13 & 9416.67 & 0.15 \\
\hline B3F2 & 5333.33 & 0.14 & 0.23 & 9.53 & 6333.33 & 0.13 & 0.37 & 19.50 & 8750.00 & 0.14 \\
\hline B3F3 & 6000.00 & 0.14 & 0.25 & 10.93 & 7166.67 & 0.13 & 0.38 & 20.84 & 8916.67 & 0.14 \\
\hline B4F1 & 5333.33 & 0.14 & 0.23 & 6.94 & 7750.00 & 0.14 & 0.36 & 16.63 & 9250.00 & 0.15 \\
\hline B4F2 & 4333.33 & 0.15 & 0.28 & 9.96 & 6500.00 & 0.15 & 0.39 & 20.65 & 8916.67 & 0.17 \\
\hline B4F3 & 5333.33 & 0.16 & 0.31 & 11.36 & 7416.67 & 0.14 & 0.42 & 21.20 & 8250.00 & 0.15 \\
\hline LSD & ns & ns & $\mathrm{ns}$ & ns & ns & ns & ns & ns & ns & $\mathrm{ns}$ \\
\hline
\end{tabular}

Note. ns - not significant.

\subsection{Tuber Yield}

Number of seed yams per hectare significantly $(\mathrm{p}=0.05)$ decreased by $32.7 \%, 18.4 \%$ and $44.9 \%$ for biochar rates of 5,10 and $15 \mathrm{t} \mathrm{ha}^{-1}$ respectively compared to the control (Table 6). Plots without biochar had the highest number (5444.00) of seed yam per hectare. Biochar effect on total number of yams harvested per hectare and number of marketable yams per hectare were however not significant. Plots treated with biochar had the highest number of marketable yams compared to the control. The highest level of biochar $\left(15 \mathrm{tha}^{-1}\right)$ recorded the highest number of marketable yams per hectare. There was however no significant difference for the interaction of biochar and fertilizer application on yam. Biochar and fertilizer treatment effect on total yam weight $\left(\mathrm{t} \mathrm{ha}^{-1}\right)$, marketable yam weight and seed yam weight $\left(\mathrm{t} \mathrm{ha}^{-1}\right)$ were not significant and did not follow any definite sequence (Table 7).

Table 6. Biochar effect on total number of yams harvested $\left(\mathrm{ha}^{-1}\right)$, number of marketable yams $\left(\mathrm{ha}^{-1}\right)$ and number of seed yams $\left(\mathrm{ha}^{-1}\right)$

\begin{tabular}{llll}
\hline & $\begin{array}{l}\text { Total number of yam } \\
\text { harvested }\left(\mathbf{h a}^{-1}\right)\end{array}$ & $\begin{array}{l}\text { Number of marketable } \\
\text { yams }\left(\mathbf{h a}^{-1}\right)\end{array}$ & $\begin{array}{l}\text { Number of seed yams } \\
\left(\mathbf{h a}^{-1}\right)\end{array}$ \\
\hline B1 & 11111.11 & 5666.67 & 5444.44 \\
B2 & 9333.33 & 5777.78 & 3666.67 \\
B3 & 10222.22 & 5777.78 & 4444.44 \\
B4 & 9333.33 & 6333.33 & 3000.00 \\
LSD & ns & ns & $1072.6^{*}$ \\
\hline
\end{tabular}

Note. * - significant; ns - not significant. 
Table 7. Biochar and inorganic fertiliser effect on total yam yield $\left(\mathrm{t} \mathrm{ha}^{-1}\right)$, marketable yam yield $\left(\mathrm{t} \mathrm{ha}^{-1}\right)$ and seed yam yield $\left(\mathrm{tha}^{-1}\right)$

\begin{tabular}{llll}
\hline & Total yam yield $\left(\mathbf{t ~ h a}^{-\mathbf{1}}\right)$ & Marketable yam yield $\left(\mathbf{t h a}^{-\mathbf{1}}\right)$ & Seed yam yield $\left(\mathbf{t} \mathbf{~ h a}^{-\mathbf{1}}\right)$ \\
\hline $\mathrm{B} 1 \mathrm{~F} 1$ & 11.93 & 10.43 & 1.50 \\
$\mathrm{~B} 1 \mathrm{F2}$ & 13.90 & 11.27 & 2.63 \\
$\mathrm{~B} 1 \mathrm{~F} 3$ & 9.03 & 2.97 \\
$\mathrm{~B} 2 \mathrm{~F} 1$ & 12.00 & 7.63 & 2.23 \\
$\mathrm{~B} 2 \mathrm{~F} 2$ & 9.87 & 11.67 & 1.70 \\
$\mathrm{~B} 2 \mathrm{~F} 3$ & 14.13 & 13.97 & 2.47 \\
$\mathrm{~B} 3 \mathrm{~F} 1$ & 15.67 & 15.47 & 2.07 \\
$\mathrm{~B} 3 \mathrm{~F} 2$ & 17.53 & 11.90 & 1.70 \\
$\mathrm{~B} 3 \mathrm{~F} 3$ & 13.60 & 12.20 & 2.47 \\
$\mathrm{~B} 4 \mathrm{~F} 1$ & 14.67 & 15.27 & 8.67 \\
B4F2 & 16.13 & 9.13 & 2.20 \\
B4F3 & 11.33 & 15.23 & 1.17 \\
LSD & 16.40 & $\mathrm{~ns}$ & $\mathrm{~ns}$ \\
\hline
\end{tabular}

Note. ns - not significant.

\subsection{Total Dry Matter}

The application of fertilizer significantly $(\mathrm{p}=0.05)$ influenced total dry matter of yam at 24 WAP and at harvest $(p=0.02)$ (Figure 3). Total dry matter increased with increasing fertilizer rate compared to the control. At 24 WAP, total dry matter was significantly increased by $12.9 \%$ and $0.82 \%$ respectively for $60-60-60 \mathrm{~N}-\mathrm{P}_{2} \mathrm{O}_{5}-\mathrm{K}_{2} \mathrm{O}$ and 30-30-30 N-P $\mathrm{P}_{2} \mathrm{O}_{5}-\mathrm{K}_{2} \mathrm{O}$ fertilizer rate. At harvest, the dry sample weight was also significantly increased by $3.31 \%$ and $1.19 \%$ for the same fertilizer rates. The influence of fertilizer on total dry matter at 8 WAP was however not significant. Similarly the interaction between biochar and fertilizer application on total dry matter was also not significant.

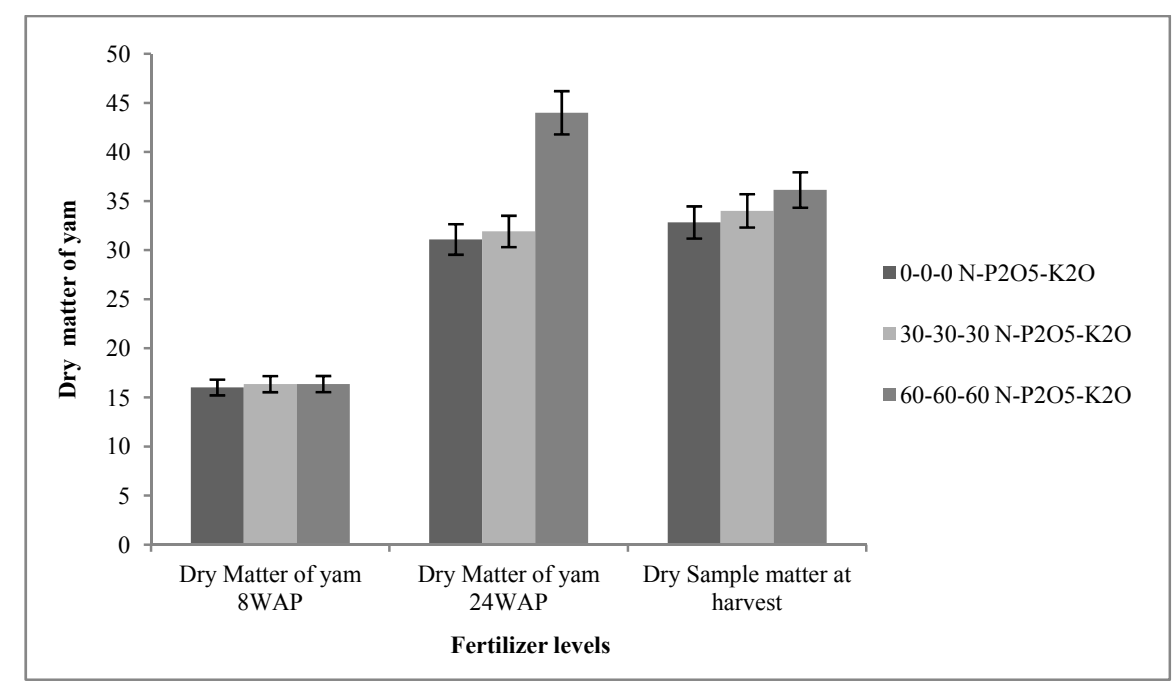

Figure 3. Inorganic fertilizer effects on total dry matter yield of yam at $8 \mathrm{WAP}(\%), 24 \mathrm{WAP}(\%)$ and at harvest (\%) 


\section{Discussion}

\subsection{Soil Chemical Properties after Harvest}

The general increase in most of the initial soil parameters following amendment with biochar and fertilizer may be explained by an increase in nutrient addition and retention as a result of their application to the soil. The biochar used in the study had higher values of $\mathrm{pH}$, exchangeable $(\mathrm{K}, \mathrm{Ca}, \mathrm{Mg}, \mathrm{Na})$, organic matter, organic $\mathrm{C}$ and total $\mathrm{N}$ compared to the initial soil used for the experiment. Increase in soil parameters as a result of biochar and fertilizer amendment has been similarly reported by several workers (Utomo, Guritno, \& Soehono, 2012; Zhang et al., 2012; Chintala et al., 2014a) and has been attributed to the nutrient content of the soil amendments used and the greater nutrient retention of the biochar applied to the soil.

Although the effect of the treatments on soil chemical properties was not significant in this study, the nature of biochar applied, the crop used and interval between biochar application and analysis of its effect, may have contributed to this finding. Major, Lehmann, Rondon, and Goodale (2010) reported that the beneficial effects of applying biochar to soil improve with time. Chan and Xu (2009) also suggested that the addition of freshly made biochar to soil does not consistently improve soil conditions. According to Liang (2006), the effect of biochar on nutrient availability is due to an increase in surface oxidation and cation exchange capacity which intensifies over time. Aged biochar with a much greater CEC may therefore have had a much greater nutrient retention capacity than the freshly made biochar used in this study.

Generally in yam production, one season of cropping results in a rapid decline in soil fertility due to the high soil nutrient mining by the crop. A ton of yam tubers is reported to extract 3.8-4.0 kg N, 0.39-1.1 $\mathrm{kg} \mathrm{P}_{2} \mathrm{O}_{5}$, and 4.2-5.9 $\mathrm{kg} \mathrm{K}_{2} \mathrm{O}$ from the soil (Le Buanec, 1972). This implies that for a high nutrient demanding crop like yam, applied biochar should be allowed to age before planting. Higher levels of nutrients may also be required to elicit significant responses.

The decline in total $\mathrm{N}$ among the treatments compared to the control after harvest may be due to the rapid mineralization of the labile $\mathrm{C}$ fraction of the biochar as result of its high $\mathrm{C}: \mathrm{N}$ ratio (263.05). Kolb, Fermanich, and Dornbush (2009) reported of similar finding in four soils from Wisconsin using manure-pine biochar. This high ratio is expected to cause $\mathrm{N}$ immobilisation and possibly induce $\mathrm{N}$ deficiency of plants when applied to soil alone (Lehmann \& Joseph 2009; Chintala et al., 2014c).

The significant reduction in soil $\mathrm{pH}$ and increase in soil $\mathrm{K}$ as a result of fertilization observed in this experiment may be due to the acidifying effect on the soil due to the nitrification process of the ammonium sulphate fertilizer used in the experiment. Dharmakeerthi, Chandrasiri, and Edirimanne (2012) in their work on Hevea brasiliensis using rubber wood biochar and liquid fertilizer also reported similar findings and attributed the reduction in soil $\mathrm{pH}$ to ammonium sulphate fertilizer applied to the treatments. Ammonium or ammonium forming fertilizers are known to cause a reduction in soil $\mathrm{pH}$ over time. The increase in soil $\mathrm{K}$, as result of fertilizer application, has also been reported by Agbede and Adekiya (2012) in their work on okra in an Alfisol in the forest - savanna transition zone of south western Nigeria.

\subsection{Vegetative Growth Parameters}

The non-significant effect of biochar application on the sprouting of yam setts observed in this study may be attributed to physiological differences in the yam setts used in planting. The head portion of yam setts has been reported to sprout and emerge faster than the lower portion (Tschannen, 2003). It is therefore likely that the influence of biochar on sprouting of the setts was influenced by the portion of the yam from which the sett was taken, thus accounting for the non-significant differences in treatments. The time of sprouting after sowing is of importance for uniformity of stand, and contributes to varying tuber maturity stages and sizes at harvest.

The non-significant difference in vine girth, vine length and number of leaves as a result of biochar and fertilizer application in this study may also have been due to the age, type, and rate of application of biochar and plant species used.

Freshly produced biochar is hydrophobic and contains few polar, functional groups at the surface (Cheng, Lehmann, Thies, \& Burton, 2008; Chintala et al., 2014b). Biochar however develops reactive surfaces with time after exposure to water and oxygen in the soil, which allows it to adsorb nutrients, reduce leaching (B. Singh, B. P. Singh, \& Cowie, 2010; Chintala et al., 2013a; Chintala et al., 2013b) and contribute to increased fertilizer use efficiency. Biochar also retains some of its feedstock nutrients in the biochar ash. Therefore biochar produced from nutrient rich feedstock such as animal manure will have high nutrient content than biochar produced from lignin rich plant biomass feed stocks (Filiberto \& Gaunt, 2013). Alburquerque et al. (2014) also reported that nutrient-poor feedstock biochar may have limited soil fertility benefits in the short term leading to little 
improvement in the crop growth. Therefore the wood shaving feedstock used to produce the biochar may have led to the non-significant difference in the crop vegetative growth.

The quantity of biochar used in this experiment was probably not sufficient to produce a significant difference in a high soil nutrient mining crop like yam. Several studies, which have reported considerable improvement in the yield of various crops species with rates from $5-50 \mathrm{t} \mathrm{ha}^{-1}$ and appropriate nutrient management have mainly been on cereals, vegetables and legumes crops with short maturity periods (Blackwell, Krull, Butler, Herbert, \& Solaiman, 2010; Glaser, Haumaier, Guggenberger, \& Zech, 2001).

Therefore yam, which is a high nutrient demanding crop and has a long maturity period, may require higher application rates of biochar.

\subsection{Yields Component of Yam}

The results showed that biochar and fertilizer did not significantly influence yield. This may be due to the fact that the treatments did not significantly affect vegetative growth parameters which translated to the yields. Increase in vegetative growth helps in efficient interception of solar radiation (Okwuowulu, 1995) which results in better tuber bulking ability. Photosynthetic efficiency in the growth of yam, determines the size of the tuber (Orkwor \& Adeniji, 1998). Additionally, the limited rainfall experienced during the tuber bulking phase from the month of July to September (Table 1) may have contributed to the non-significant effects on the yield of the crop even with soil amendment. This supports the findings by (Craufurd, Summerfield, Asiedu, \& Vara Prasad, 2001) that the tuber bulking phase in the growth of yam is highly sensitive to water stress.

The non-significant effect of the treatments on yields observed in this study however contrasts the findings of (Yamato, Okimori, Wibowo, Anshori, \& Ogawa, 2006; Schulz \& Glaser, 2012) which found significant increase in crop yield as a result of biochar and fertilizer addition. They attributed it to biochar's ability to efficiently utilize nutrients by holding ammonium ions in soils and inhibiting nitrogen fertilizer nitrification.

Biochar however, caused a reduction in number of seed yams per hectare but a higher number of marketable yams per hectare compared to other treatments in this study. This observation suggests that biochar favours the growth of larger tubers (marketable yam) which is the real component of economic yield needed by farmers. Biochar can thus be recommended when the objective is for the production of larger tubers (marketable yam).

\subsection{Effect on Total Dry Matter}

The significant increase in total dry matter of yam on fertilized plots at 24 WAP and at harvest observed in this study may be due to a higher availability of nutrient and timing of the fertilizer application at the vegetative and tuber bulking stage of the crop development. The fertilizer used in this experiment was split applied at 8 and 16 WAP. Hgaza, Diby, Assa, and Ake (2010) in their work on D. alata L. also reported of increased dry matter of yam as result of fertilizer application. Contrary to this, Orkwor and Adeniji (1998) observed no effect of fertilisation on the dry matter content of yam. The timing of application of soil amendments in yam production should therefore be planned so that the crop can make good use of the nutrients they provide.

\section{Conclusions}

The biochar and inorganic fertilizer applied in this study did not have a significant effect on soil parameters with the exception of total $\mathrm{N}$, vegetative growth and tuber yield of yam. The number of seed yams per hectare was however significantly decreased with biochar application. These effects were attributed to the age, rate of application of biochar and the type of crop grown (high nutrient requirement of yam). Since recommended application rates for any soil amendment must be based on extensive field testing and given the variability in biochar material and soils, there is the need for extensive field testing (on yam variety types, time of application of the soil amendment, aged and higher rate of biochar application) before making a general recommendation of biochar application in yam production. Notwithstanding this, aged biochar and higher rates of biochar may be useful for increasing the yield of marketing yam tubers.

\section{Acknowledgements}

The study was financed by the West African Agricultural Productivity Programme (WAAPP) through (CSIR) Crops Research Institute (CRI).

\section{Reference}

Adeleye, E. O., Ayeni, L. S., \& Ojeniyi, S. O. (2010). Effect of Poultry Manure on Soil Physico-Chemical Properties, Leaf Nutrient Contents and Yield of Yam (Dioscorea rotundata) on Alfisol in Southwestern Nigeria. Journal of American Science, 6(10), 871-878. 
Adu, S. V., \& Asiamah, R. D. (1992). Soils of the Ayensu-Densu Basin, Central, Eastern and Greater Accra Regions of Ghana (No. 9, p. 117). Council for Scientific and Industrial Research (CSIR) - Soil Research Institute Memoir.

Agbede, T. M., \& Adekiya, A. O. (2012). Effect of wood ash, poultry manure and NPK fertilizer on soil and leaf nutrient composition, growth and yield of okra (Abelmoschus esculentus). Emir. J. Food Agric., 24(4), 314-321.

Akanbi, W. B., Olaniran, O. A., \& Olaniyan, A. B. (2007). Effects of integrated use of organic and inorganic nutrient sources on growth and tuber characteristics of white yam (Dioscorea rotundata) cv. ehuru. African Crop Science Conference Proceedings, 8, 359-363.

Alburquerque, J. A., Calero, J. M., Barrón, V., Torrent, J., del Campillo, M. C., Gallardo, A., \& Villar, R. (2014). Effects of biochars produced from different feedstocks on soil properties and sunflower growth. J. Plant Nutr. Soil Sci., 177, 16-25. http://dx.doi.org/10.1002/jpln.201200652

Babaleye, T. (2003). West Africa: Improving yam production technology. ANA-BIA Supplement Issue/Edition, $463,56-59$.

Baldock, J. A., \& Smernik, R. J. (2002). Chemical composition and bioavailability of thermally altered Pinus resinosa (Red pine) wood. Organic Geochemistry, 33(9), 1093-1109. http://dx.doi.org/10.1016/S0146-6380(02)00062-1

Blackwell, P., Krull, E., Butler, G., Herbert, A., \& Solaiman, Z. (2010). Effect of banded biochar on dryland wheat production and fertilizer use in South-Western Australia: An agronomic and economic perspective. Australian Journal of Soil Research, 48, 531-545. http://dx.doi.org/10.1071/sr10014

Bol, R., Amelung, W., Friedrich, C., \& Ostle, N. (2000). Tracing dung-derived carbon in temperate grassland using 13C natural abundance measurement. Soil Biol. Biochem., 32(10), 1337-1343. http://dx.doi.org/10.1016/S0038-0717(00)00022-5

Chan, K. Y., \& Xu, Z. (2009). Biochar: Nutrient Properties and Their Enhancement. In J. Lehmann \& S. Joseph (Eds.), Biochar for environmental management: Science and Technology. Earthscan, London. http://dx.doi.org/10.1021/bi901308x

Chan, K. Y., Van Zwieten, L., Meszaros, I., Downie, A., \& Joseph, S. (2008). Using poultry litter biochars as soil amendments. Australian Journal of Soil Research, 46, 437-444. http://dx.doi.org/10.1071/SR08036

Cheng, C.-H., Lehmann, J., Thies, J. E., \& Burton, S. D. (2008). Stability of black carbon in soils across a climatic gradient. $J$ Geophys Res: Biogeosciences, $2005-2012, \quad 113$. http://dx.doi.org/10.1029/2007JG000642

Chintala, R., Clay, D. E., Schumacher, T. E., Malo, D. D., \& Julson, J. L. (2013c). Optimization of Oxygen parameters for analyzing carbon and nitrogen in biochar materials. Analytical Letters, 46(3), 532-538. http://dx.doi.org/10.1080/00032719.2012.721103

Chintala, R., Mollinedo, J., Schumacher, T. E., Malo, D. D., \& Julson, J. L. (2014a). Effect of biochars on chemical properties of acidic soil. Archives of Agronomy and Soil Science, 60(3), 393-404. http://dx.doi.org/10.1080/03650340.2013.789870

Chintala, R., Mollinedo, J., Schumacher, T. E., Malo, D. D., Papiernik, S., Clay, D. E., ... Gulbrandson, D. W. (2013a). Nitrate sorption and desorption by biochars produced from microwave pyrolysis. Microporous and Mesoporous Materials, 179, 250-257. http://dx.doi.org/10.1016/j.micromeso.2013.05.023

Chintala, R., Owen, R. K., Schumacher, T. E., Spokas, K. A., McDonald, L. M., Malo, D. D., ... Bleakley, B. (2014). Denitrification kinetics in biomass and biochar amended soils of different landscape positions. Environmental Science and Pollution Research. http://dx.doi.org/10.1007/s11356-014-3762-2.

Chintala, R., Schumacher, T. E., Kumar, S., Malo, D. D., Rice, J., Bleakley, B., ... Gu, Z. R. (2014b). Molecular characterization of biochar materials and their influence on microbiological properties of soil. Journal of Hazardous Materials, 279, 244-256. http://dx.doi.org/10.1016/j.jhazmat.2014.06.074

Chintala, R., Schumacher, T. E., McDonald, L. M., Clay, D. E., Malo, D. D., Clay, S. A., ... Julson, J. L. (2013b). Phosphorus sorption and availability in biochars and soil biochar mixtures. CLEAN-Soil Air Water, 41(9999), 1-9.

Craufurd, P. Q., Summerfield, R. J., Asiedu, R., \& Vara Prasad, P. V. (2001). Dormancy in Yams. Exptl Agric., 37 , 147-181. http://dx.doi.org/10.1017/S001447970100206X 
Dharmakeerthi, R. S., Chandrasiri, J. A. S., \& Edirimanne, V. U. (2012). Effect of rubber wood biochar on nutrition and growth of nursery plants of Hevea brasiliensis established in an Ultisol. Springer Plus. http://dx.doi.org/10.1186/2193-1801-1-84

Ernest, J., \& O'Sullivan, J. (2004). Improved fallow and live-staking of yam using Gliricidia sepiumin in Papua New Guinea. In Proceedings of the $4^{\text {th }}$ International Crop Science Congress, Brisbane.

Eze, S. C., Eze, E. I., Ameh, G. I., \& Dansi, A. (2013). Effect of some botanical extracts on post-harvest losses of yam (Dioscorea rotundata) in improved yam barn in Nigeria. African Journal of Biotechnology, 12(16), 1962-1967. http://dx.doi.org/10.5897/AJB12.754

Filiberto, D. M., \& Gaunt, J. L. (2013). Practicality of Biochar Additions to Enhance Soil and Crop Productivity. Agriculture, 3(4), 715-725. http://dx.doi.org/10.3390/agriculture3040715

Food and Agricultural Organisation. (2012). Statistics Division. Rome, Italy.

Glaser, B., Haumaier, L., Guggenberger, G., \& Zech, W. (2001). The Terra Preta phenomenon: A model for sustainable agriculture in the humid tropics. Naturwissenschaften, 88, 37-41. http://dx.doi.org/10.1007/s001140000193

Hgaza, V. K., Diby, L. N., Assa, A., \& Ake, S. (2010). How fertilization affects yam (Dioscorea alata L.) growth and tuber yield across the years. African Journal of Plant Science, 4(3), 53-60.

Karve, P., Prabhune, R., Shackley, S., Carter, S., Anderson, P., Sohi, S., ... Tanger, P. (2009). Biochar for carbon reduction, sustainable agriculture and soil management. Final Report submitted to Asia-Pacific Network for Global Change Research. Project reference number: ARCP2009-12nSY-Karve.

Kolb, S. E., Fermanich, K. J., \& Dornbush, M. E. (2009). Effect of charcoal quantity on microbial biomass and activity in temperate soils. Soil Science Society America Journal, 73(4), 1173-1181. http://dx.doi.org/10.2136/sssaj2008.0232

Le Buanec, B. (1972). GERDAT. Groupement d'Etudes et de Recherches pour le Développement de l'Agronomie Tropicale. IRAT. Institut de Recherches. Cited in S. A. Ennin, G. Bolfrey-Arku, V. M. Anchirinah, \& E. Otoo 2003 IFS proposal.

Lehmann, J., \& Rondon, M. (2006). Bio-Char Soil Management on Highly Weathered Soils in the Humid Tropics. Publishers Taylor and Francis Group 6000 Broken Sound Parkway NW.

Lehmann, J., \& Joseph, S. (2009). Biochar for environmental management, Science and Technology. Earthscan, London.

Lehmann, J., Pereira da Silva Jr, J., Steiner, C., Nehls, T., Zech, W., \& Glaser, B. (2003). Nutrient availability and leaching in an archaeological Anthrosol and a Ferralsol of the Central Amazon basin: Fertilizer, manure and charcoal amendments. Plant Soil, 249, 343-357. http://dx.doi.org/10.1023/A:1022833116184

Liang, B., Lehmann, J., Solomon, D., Kinyangi, J., Grossman, J., O’Neill, B., ... Neves, E. G. (2006). Black carbon increases cation exchange capacity in soils. Soil Science Society of America Journal, 70(5), 1719-1730. http://dx.doi.org/10.2136/sssaj2005.0383

Major, J., Lehmann, J., Rondon, M., \& Goodale, C. (2010). Fate of soil-applied black carbon: Downward migration, leaching and soil respiration. Global Change Biology, 16(4), 1366-1379. http://dx.doi.org/10.1111/j.1365-2486.2009.02044.x

O'Sullivan, J. N. (2010). Yam nutrition: nutrient disorders and soil fertility management. ACIAR Monograph No. 144. Australian Centre for International Agricultural Research.

Okwuowulu, P. A. (1995). Yield response to edible yam (Dioscorea sp.) to time of fertilizer application and age at harvest in an Ultisol in the humid zone of Southeastern Nigeria. African Journal of Root and Tuber Crops, 1, 6-10.

Orkwor, G. C., \& Adeniji, A. A. (1998). Production constraints and available technologies for food yam (Dioscorea spp.) production in Nigeria. In J. Berthaud, N. Bricas, \& J. Mardand (Eds.), Yam, old plant and crop for the future (pp. 409-414). Actes du Seminaire Inter. Cirad Intra- Orstom- Coraf. Montpellier, France.

Otoo, E., Anchirinah, V. M., Ennin, S. A., \& Asiedu, R. (2008). Sustainable yam production in Ghana - The non-staking option. Journal of Food, Agriculture and Environmental, 6(3\&4), 391-396.

Schulz, H., \& Glaser, B. (2012). Effects of biochar compared to organic and inorganic fertilizers on soil quality 
and plant growth in a greenhouse experiment. $J$ Plant Nutr Soil Sci, 175, 410-422. http://dx.doi.org/10.1002/jpln.201100143

Singh, B., Singh, B. P., \& Cowie, A. L. (2010). Characterisation and evaluation of biochars for their application as a soil amendment. Soil Research, 48(7), 516-525. http://dx.doi.org/10.1071/SR10058

Solaiman, Z. M., Blackwell, P., Abbott, L. K., \& Storer, P. (2010). Direct and residual effect of biochar application on mycorrhizal root colonisation, growth and nutrition of wheat. CSIRO Publishing. The Free library.

Tschannen, A. (2003). Characteristics of setts. Controlling Post-harvest Losses of Yam (Dioscorea spp.) by Application of Gibberellic Acid (p. 122, Doctoral dissertation). Swiss Federal Institute of Technology Zurich for the degree of Technical Sciences. Retrieved from http://e-collection.library.ethz.ch/eserv/eth:26304/eth-26304-02.pdf

Utomo, W. H., Guritno, B., \& Soehono, L. A. (2012). The Effect of Biochar on the Growth and N Fertilizer Requirement of Maize (Zea mays L.) in Green House Experiment. Journal of Agricultural Science, 4(5), 255-262. http://dx.doi.org/10.5539/jas.v4n5p255

Yamato, M., Okimori, Y., Wibowo, I. F., Anshori, S., \& Ogawa, M. (2006). Effects of the application of charred bark of Acacia mangium on the yield of maize, cowpea and peanut, and soil chemical properties in South Sumatra, Indonesia. Soil Sci. Plant Nutr., 52, 489-495. http://dx.doi.org/10.1111/j.1747-0765.2006.00065.x

Zhang, A., Bian, R., Pan, G., Cui, L., Hussain, Q., Li, L., ... Yu, X. (2012). Effects of biochar amendment on soil quality, crop yield and greenhouse gas emission in a Chinese rice paddy: A field study of 2 consecutive rice growing cycles. Field Crops Research, 127, 153-160. http://dx.doi.org/10.1016/j.fcr.2011.11.020

\section{Copyrights}

Copyright for this article is retained by the author(s), with first publication rights granted to the journal.

This is an open-access article distributed under the terms and conditions of the Creative Commons Attribution license (http://creativecommons.org/licenses/by/3.0/). 